\title{
Do Ideological and Political Motives Really Matter in the Pub- lic Choice of Local Services MAnagement? EVIDENCE FROM URBAN WATER SERVICES IN SPAIN
}

Andrés J Picazo-Tadeo*; Alberto Ruiz-Villaverde**; Francisco González-Gómez**; Jorge Guardiola Wanden-Berghe**.

Abstract- According to the literature, local govemment decisions regarding the management of municipal servic es are mainly based on pragmatic reasons, ideological and political motives having little influence. However, in some munic ipal services, such as the urban water service, ideological and political factors could play a more relevant role when it comes to deciding the management altemative. The a im of this paper is to study the influence of ideological and political motives on the choice of management for the urban water service in 734 munic ipa lities loc ated in the south of Spain. One of our contributions is that we use a considerably more detailed set of variables representing politic al and ideologic al motives than most of the previous research. Similarly, the value of the variables that explain local politicians' decisions is that observed at the time decision making occurs and not at a later date. Our results reveal that the two largest parties disputing the centre of the Spanish politic al spectrum employ similar strategies when choosing a management alternative for the water service. However, the city councils govemed by the most left-wing party are more reluctant to privatise. Finally, political variables such as stakeholder lobbying affect local govemment decision making.

Keywords.- Urban water services; local govemments; privatisation; contracting-out; ideologic al and politic al motives; Public Choice.

JEl Classific ation.- L33, C 25, H83.

*Picazo-Tadeo, Andrés J.

(andres.j.picazo@uv.es)
*UNIVERSIDAD DE VALENCIA

Facultad de Economía Avda dels Tarongers s/n 46022 VALENCIA (SPAIN)

Tlf.: +34 963828 349/62
**Ruiz-Villaverde, Alberto (albertorv@ugr.es)

**González-Gómez, Francisco (fcojose@ugr.es)

**Jorge Guardiola Wanden-Berghe (jguardiola@ugr.es)

**UNIVERSIDAD DE GRANADA Facultad de Ciencias Económicas y Empresariales Campus de Cartuja, s/n, 18071 GRANADA (Spain) Tlf.: + 34958244261 


\section{INIRODUCTION}

Over the last quarter of a century, most industria lised countries, a lbeit to a different extent, have made changes to their legislation aimed at stimulating the contracting out of municipal services. In general, local govemments have been given the power to choose who manages municipal services. As a result, some munic ipalities decided to contract out, while in others these services a re still provided by the city or town council itself. At the same time, researchers have become increasingly interested in ascertaining the reasons behind the difference in behaviour of local politic ians regarding the systems chosen for procuring municipal services. Why do some local govemments choose to contract out municipal servic es while others do not? is the question that researc hers have sought to answer.

Following the pioneer research by Ferris (1986), which analysed the causes behind cities in the United States contracting out municipal services, numerous papers have studied the deteminants of local govemment decisions regarding the management of municipal services. Generally speaking, applied research highlights the fact that these decisions are mainly pragmatic (Bel and Fageda 2007, 2009a). Two of the main reasons found are the need to reduce cost inefficiencies and city councils' lack of financial capacity.

Likewise, the minimal importance given by the literature to variables representing ideological preferences and political motives when explaining the choice of management for municipal services stands out. On the one hand, researchers have placed more emphasis on analysing other types of determinants -such as those of an economic nature. For this reason, studies frequently omit variables representing ideology, political motives being only partially considered. On the other hand, the variables representing ideology are not normally significant when explaining local govemment decisions.

The choice of policy, the behaviour of politicians and their motives are issues that have been widely studied in the field of Public Choice. In general, this approach undertakes an economic analysis of political behaviour using the analytical tools typical of the neoclassical theory. The political system is considered a market in which the players -politicians and public employees- interact in pursuit 
of their own personal interests. This view of politics and bureaucracy can be found in the seminal work by Downs (1957) and also in the research by Black (1958), Buchanan and Tullock (1962), Stigler (1965) or Niskanen (1971), a mong others.

The models based on the citizen-candidate approach, developed by Osbome and Slivinski (1996), Besley and Coate (1997) and Dixit and Londregan (1998) represent a significant advance in the analysis of Public Choice. This view goes beyond the Downsian approach to political behaviour, strictly opportunistic and selfish (Downs, 1957 and Lindbeck and Weibull, 1987), recognising that political motives in a democracy revolve around two interests. On the one hand, as in utilita rianism, politicians aim to win the elections to occupy a government post or maintain it. On the other hand, motives stem from politicians preferring to apply certa in polic ies ahead of others.

Such political interests undoubtedly play an important role in local govemment decisions regarding the management of municipal services. However, it is reasonable to believe that said importance may vary from one service to another; for example, ideological and political motives will not foreseeably have the same influence on decisions regarding the management of services that are as different as social welfare, sports services or the urban water service. This suggests it is worth analysing the influence of ideological and political motives on each type of service.

Ideological and political motivationscould be expected to have a greater influence on local govemment decisions regarding who will provide the urban water service, due to its characteristics. Although its management may be delegated to public or private fims, in most developed countries the provision of urban water services, as well as other services such as garbage collection, is the responsibility of the public sector because of the positive extemalities they generate -public health. Furthemore, water is a special consumer good to which universal access must be guaranteed -at least to the level which is considered essential for life-, be affordable for any given level of income and must reach households in conditions that comply with certa in standards of quality. Finally, the water industry is made up of local monopolies, which means the service is often subject to regulation and political control. 
This research a ims to analyse the deteminants of local govemments' choice of management system for the urban water supply, paying special attention to the ideological and political factor in said decisions. The analysis is undertaken using data from the period 1986-2006 for 734 municipalities in Andalucía, a Spanish region located in the south of the Iberian Peninsula. Our main contribution to the literature in this field of research is two-fold. Firstly, while previous studies usually only distinguish between left-wing and right-wing ideologies, we incorporate a wide range of variables that represent ideology, some of which have not been used previously in the literature. In the second place, the value of the explanatory variables is taken at the time the local govemment makes the decision on the management of the water service, instead of at a later date as is nomally the case in most of the previous research.

The most noteworthy result in regard to ideological motivations is that the two la rgest parties disputing the centre of the Spanish politic al spectrum do not differ in the strategy they employ to choose a management altemative for the water service. However, the city councils govemed by the most left-wing party are more reluctant to privatise. Finally, politic al variables such as stakeholder lobbying affect local govemment decision making.

The rest of the article is organised as follows. Section 2 provides a review of the literature. Section 3 describes the data and Section 4 explains the methodology and the results. The last section summarises and concludes.

\section{REVIEW OF THE LITERATURE}

This section reviews the research that has included variables representing ideology and political behaviour in the a nalysis of local govemment decision making regarding the type of management chosen to run the provision of the urban water supply.

After reviewing the literature, we found it striking that ideological factors and political behaviour had received so little attention as explanatory variables behind local govemment decisions regarding the management of the urban water service. Furthermore, in keeping with most of the research camed out for other mu- 
nic ipal services, the results of the few studies of the urban water service support the thesis that pragmatic reasons are more decisive than ideological and political motives.

The main reference for the relationship between ideological and political motivations and the decision regarding who manages the urban water service is the series of papers written by Gemà Bel and collaborators for the northeast of Spain. Bel and Fageda (2008) a nalyses the management choice for the rubbish collection and water supply services. The authors include a variable representing the degree of industrial activity as a proxy of the influence of lobbies. In addition, they incorporate a variable denoting the political party that the Mayor belongs to, another of the percentage of votes won by conservative parties in the national elections and a series of variables that combine the two foregoing variables. The conclusion is that the influence of political interests is more relevant than ideology when explaining priva tisation decisions.

Bel et al. (2009) explores the causes behind the privatisation of rubbish collection and water services in small towns including, among others, a dichotomic variable to distinguish whether a mayor is left or right-wing. The results show that ideological factors are not relevant when it comes to explaining the decision, while other variables such as the financial situation of the town are. Similarly, Bel and Fageda (2009b) concludes that ideological and political factors do not play an important role in local govemment decisions to share the management of the municipal distribution service with private firms.

Martínez-Espiñeira et al. (2009), in a study a lso caried out for Spa in, include a variable that represents the ideology of mayors: left-wing versus right-wing. The main result is that when towns are govemed by left-wing mayors, the water service is less likely to be contracted out to private fims. Another important finding is that in cities where economic activity is more intense, the likelihood of the private sector entering the market is greater, due to the fact that higher profits are also expected.

Miralles (2009) and González-Gómez and Guardiola (2009) employ a duration model to analyse decisions to contract out the munic ipal water service. Both stud- 
ies are camied out on a sample of Spanish towns. On the one hand, Miralles (2009) finds that the proximity effect, financial stress and the pressure exercised by lobbies influence the decision to privatise. However, the paper also underlines the fact that the statistical signific ance of these variablescan change over time. Likewise, it is concluded that ideology is only minimally significant when explaining privatisation trends. González-Gómez and Guardiola (2009), on the other hand, includes a variable to distinguish between towns govemed by right-wing and left-wing political parties. They conclude that ideology is not a decisive factor in the decisions taken by local govemments to contract out. In this research, the authors conclude that the complexity of the environment, economies of scale, financial constraints and local govemment stability are the factors that have the greatest influence on the decision.

In the research by Tavares and Camöes (2007) on the provision of five municipal senvices in Portugal, the variable representing the ideology of the party in power in the local govemment was not statistically significant in the choice of manager in the areas of environment, water supply or rubbish collection. The variable that represents the interests of lobbies, made up of public employees in the town, was not representative either. In the research camied out for France by Ménard and Saussier (2000) and Carpentier et al. (2006), no variables representing ideology are included to analyse local govemment decisions regarding the management of the urban water service. The first of the two papers concludes that the likelihood of the service being delegated to a private company is greater when providing the service is expected to yield higher profits. The second paper concludes that towns tend to delegate management to private companies when the conditions surrounding the provision of the service are more complex.

\section{DATA AND VARIABIES}

The study is carried out using data from the period 1986-2006 for 734 municipalities, which represent slightly more than $95 \%$ of the municipalities in the region. In Andalusia, as in the rest of Spain, management of the urban water service is shared by the various legal organisms. Figure 1 shows the relative importance of each in 2006. Ascan be observed, in 59\% of munic ipa lities, the urban water service is provided by the local govemment itself, whereas the remaining $41 \%$ have exter- 
nalised the service to either a public company (15\% of municipalities) or a private firm (26\%). The last figure also includes public-private partnerships, whose management is similar to that of private fims, due to business decisions, as mentioned previously, being taken by the private partner.

The question worth asking in view of this information is what factors influence local govemment decisions regarding the management of the urban water service? More specifically, this research seeks to ascertain the role that ideological and political factors play in said decisions. In order to do so, we have included a complex set of variables representing ideology and politic al behaviour, a part from the factors commonly considered in this type of study, such as munic ipality size, financial stress or income percapita. Although we would have liked to incorporate other expla natory va ria bles into the a nalysis, sta tistic al constra ints ma de this impossible. All the variables used in the research and their respective statistical sources are described in Appendix 1.

According to Downs (1957), the main objective of politic al parties is to win the elections. As a result, the number of political parties would affect the workings of democracy to a great extent. In a two-party system, both would strive to win by defending the ideas and measures that the majority of citizens-voters would be willing to support. These circumstances could lead to ambiguous situations where the ideological stances of the two parties are concemed and also result in the two coming closer ${ }^{1}$. It is therefore no surprise that the empirical studies that have represented ideology with dichotomic variables that distinguish between left and rightwing ideologies have failed to detect a relationship between ideology and local govemment decisions on the management of municipal services. However, in this paper we uphold that in multiple party scenarios², local govemment decisions can be related to ideological stances, not only in theory, but also in practice.

\footnotetext{
1 Hotelling and Downs' median-voter theorem states that if two majority parties take a political stance based on a central position, they expect to receive half of the undecided votes. However, if either of these parties departed from a central position, they would receive less than half of the votes.

2 Spain is a multiple party democracy, although in some municipalities the scenario could be considered bipartisan due to the minimal support received by minority parties.
} 
In order to capture the effect of ideological and political factors on the decision regarding who should manage the urban water senvice, we firstly consider a series of variables that represent the ideology of the Mayor, also bearing in mind whether or not he or she enjoys majority or minority rule. In the period under a nalysis, we find as many as four either national or regional political parties in local govemments in Andalusia, as well as some small independent parties which, generally speaking, only act on a local scale. In our opinion, decision making regarding the management of municipal services, and in particular urban water services, should go beyond merely distinguishing between left and right, such that the peculiarities of the parties on either side of the political spectrum can be relevant.

The two parties that enjoy the most support at national and regional level and which are striving to comer the centre of Spa nish politics a re the Partido Socia lista Obrero Español (PSOE) and the Partido Popular (PP). PSOE is a centre/left-wing party, while PP is a centre/right-wing party. Izquierda Unida (IU) is situated further to the left of PSOE on the political spectrum. There is also a regional party in Andalusia called Partido Andalucista (PA), which defends the interests of the region in the national parliament, but its ideological proposals are eclectic. Finally, on a local scale, there are independent parties that are nomally created following a rift between one of the parties with the most representatives in the local govemment and some of its members. ${ }^{3}$

Moreover, as mentioned above, in order to include the variable representing the ideology of the Mayor, we distinguished between govemments with majority and minority rule. Decision making is easier for a majority govemment. Firstly, because the govemment does not need to seek support from other political parties to pass measures and, secondly, because a mayor is more strongly supported by citizens-voters. The variables included to represent majority govemments are PP MAJORITY, PSOE MAJORITY, IU MAJORITY and PA MAJORITY, while the variables representing minority govemments a re PP MINORITY, PSOE MINORITY, IU MINORITY and PA MINORITY.

\footnotetext{
3 Independent parties were not included in our empincal analysis for two reasons. In the first place, because the sphere of activity of these parties nomally only affects one town making results difficult to interpret due to their heterogeneity. In the second place, it is necessary to exclude some variables linked to ideology in order to avoid multicollinearity problems when estimating the model.
} 
Let us remind readers that Appendix 1 includes a description of all the variables used in this research.

The political transition to democracy that took place in Spain in the second half the 1970s resulted in a decentralised model of govemment divided into four levels: national, regional, provincial and local. In order to capture the possible influence of the ideology of higher levels of govemment on the decisions taken by local govemments, the variable PROVINCIAL GOVERNMENT was used. This variable is dichotomic and takes a value of 1 when local govemment ideology coincides with the ideology of the next level of govemment, the provincial govemment. ${ }^{4}$

The variable GOVERNMENT SWITCH was included so as to verify the possible influence of a mayor's stability in office. This va riable tells whether a ma yor is enjoying a second tem in office of whether he or she has won the elections for the first time. A certain degree of vote immobility is common in Andalusia. As a result, local govemments have had the same ideology over the sample period in approximately two thirds of the municipalities.

Politicians' behaviour can also be influenced by their interest in remaining in their posts. On the one hand, the objective of remaining in office will make them more vulnerable to the pressure of lobbies, while on the other hand, the objective of being re-elected may determine when certain decisions are taken during the term. It would be logical to expect unpopular measures such as privatising the urban water service to be adopted in the early years of the term of office, in the hope that voters would have forgotten about them by the next elections. In order to represent the pressure exerted by lobbies, the following variables were included: INCOME PER CAPITA AND PUBUC EMPLOYMENT. ${ }^{5}$ Meanwhile, to verify the possible relationship between the political cycle and decision making the variable POUTCAL CYCLE

\footnotetext{
4 Initially, the research did not take into account whether the ideology of the local govemment coincided with that of the national govemment, as the influence should come from the level of govemment immediately superior. In contrast, we did consider including a variable representing coincidence of ideologies between the local and regional govemment. However, we were unable to include it in the model due to the high degree of correlation with the variable ProvinCIALGoVERNMENT.

5 Trade union membership has also been used in other studies to indicate the strength of lobbies. However, this ind ic ator does not represent the power of trade unions in Spain, as they are funded by transfers from the govemment rather than membership fees.
} 
was introduced, a dichotomic variable that denotes whether the decision to extemalise is taken during the first or the sec ond half of the legislature.

Concluding the set of political and ideological variables, information representing political initia tives a imed at encouraging associationism a mong munic ipalities has been included. Regional govemment acknowledgement of the existence of urban agglomerations, captured by the variable URBAN AGGLOMERATION and also the creation of consortiums, variable CONSORTUM, are legal bodies that facilitate the joint provision of services under one sole manager for a group of munic ipa lities.

Finally, the general variables included to explain local political decisions regarding the management of the urban water service are POPULATON, FINANCIAL BURDEN and a variable that represents the complexity of providing the service, CAPTATION SYSTEM, which informs whether water is captured by mechanical means or simply through the force of gravity.

The likelihood of extemalising the service can be expected to increase the larger the municipality, measured by the variable population. There are several reasons for this relationship. The water supply is more complex to manage in large munic ipalities, which can lead local govemments to resort to the know-how of private firms to provide the service. Likewise, transaction costs related to controlling the service and the investment per inhabitant necessary to provide the service tends to be lower in larger munic ipalities. Both these circumstances increase expected profits, making large cities more attractive for private firms (Ménard and Sa ussier 2000; Ma rtínez-Espiñeira et al. 2009).

The lack of financial resources necessary to provide the water service has been one of the main reasons why Spanish local govemments have resorted to privatisation (Ba kker 2002). Privatisation allows local govemments to gua ra ntee the provision of a general interest service and at the same time maintain a healthy financial situation. The inclusion of the financial burden of the local govemment is precisely aimed at capturing this effect. Finally, the diffic ulty that the environment entails for managing the water senvice figures prominently in local govemment decisions regarding its provision. In this sense, more complex environments should increase the likelihood of the service being extemalised (Carpertier et al. 2006). 
Table 1 presents information describing the sample for the variables used in the research. Data are provided for all municipalities, as well as for those which have contracted-out the urban water service.

Finally, in reference to the explanatory variables used, one of the contributions of this research is that they are measured at the time the decision to contract out the water service was taken rather than at a later date, as is the case in most previous studies. This is particularly important when a long sample period is being studied, as is the case in our research. As indicated by Bel and Fageda (2007), the value of the explanatory variables at time $t$, when the data are observed, may differ substantially from the value at $t-n$, when local govemments took the decision to contract out. By considering the temporary nature of the variables, we expect to enhance the explanatory power of our model. Other papers that have considered the time factor of variables are Miralles (2009), González-Gómez and Guardiola (2009) and González-Gómez et al. (2010).

\section{METHODOLOGICAL NOTIES AND RESULTS}

\subsection{Methodologic al Notes}

When choosing the manager of the urban water service, local govemments must first decide whether to continue providing the service themselves or, on the contrary, to contract out. Once this decision has been taken, if a local govemment opts for the latter, it must then choose one of two possible altematives: a public company or a private fim. ${ }^{6}$ Considering the nature of this decision process, it can be modelled using a probit selection model (Van de Ven and Van Praag, 1981), which is a specification for a binary outcome of the well-known Heckman sample selection model (Heckman 1979).

The result of the first choice is represented by the observed binary variable CONTRACTING-OUT, which takes a value 1 if the local govemment contracts out the urban water service and 0 if the service continues to be provided by the council. Let us now assume that behind this observed variable there is a latent unobserv-

\footnotetext{
${ }^{6}$ It is worth recalling that this research also considers public-private partnerships as private firms to all practical effects.
} 
able variable, namely CONTRACTING-OUT*, so that CONTRACTNG-OUT=1 if CONTRACTINGOUT*>0 and CONTRACTING-OUT=0 if CONTRACTING-OU* $\leq 0$. The result of the second binary choice, which is only observable if CONTRACTING-OUT=1, that is if the local govemment decides to contract out the urban water service, is represented by the variable PRIVATSATION, which takes a value of 1 if the senvice is contracted out to a private firm and 0 if it is contracted out to a public firm. Also, behind this decision there is a latent unobservable variable, PRIVATISATION*, such that PRIVATISATION=1 if PRIVATISATION* $>0$ and PRIVATISATION $=0$ if PRIVATISATION* $\leq 0$. This might be formalised as follows:

CONTRACTING-OUT $=\left[\begin{array}{l}1 \text { if CONTRACTING-OUT }{ }^{*}>0 \\ 0 \text { if CONTRACTING-OUT }{ }^{*} \leq 0\end{array}\right]$

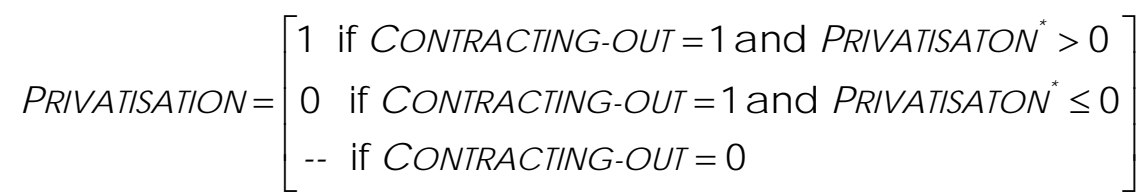

Introducing two sets of independent variables, namely X SATon, to explain our latent variables allows us to define a two-equation system. The first equation describes the probability of experiencing the selecting event, Pro-

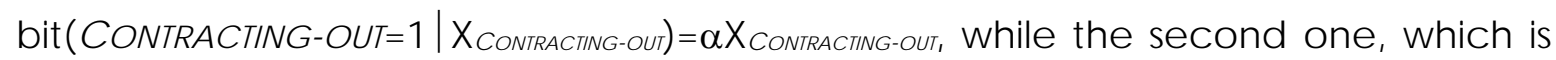
only defined if CONTRACTING-OUT=1, represents the outcome of the second choice,

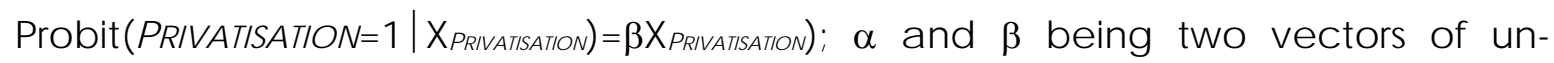
known regression parameters. Considering the particular variables used in this research to explain the decisions of contracting-out and privatisation, the twoequation system can be linearly stated as:

$$
\begin{aligned}
\text { CONTRACTING-OUT } & * \\
= & \alpha_{0}+\alpha_{1} \text { PP MAJ ORITY }+\alpha_{2} \text { PSOE MAJORITY }+\alpha_{3} \text { IU MAJ ORITY }+ \\
& \alpha_{4} \text { PA MAJORITY }+\alpha_{5} \text { PP MINORITY }+\alpha_{6} \text { PSO E MINORITY }+ \\
& \alpha_{7} \text { IU MINORITY }+\alpha_{8} \text { PA MINORITY }+\alpha_{9} \text { PROVINCIAL GOVERNMENT }+ \\
& \alpha_{10} \text { G OVERNMENT SWITCH }+\alpha_{11} \text { INC OME PER CAPITA }+ \\
& \alpha_{12} \text { PUBLIC EMPLOYMENT }+\alpha_{13} \text { URBAN AG GLOMERATION }+ \\
& \alpha_{14} \text { CONSO RTIUM }+\alpha_{15} \text { POPULATION }+\alpha_{16} \text { SQ UARE OF POPULATION }+ \\
& \alpha_{17} \text { FINANCIAL BURDEN }+\alpha_{18} \text { CAPTATION SYSTEM }+\varepsilon_{\text {CONIRACTNG OUT }}
\end{aligned}
$$




$$
\begin{aligned}
\text { PRIVATISATION }^{*}= & \beta_{0}+\beta_{1} \text { PP MAJORITY }+\beta_{2} \text { PSOE MAJORITY }+\beta_{3} \text { IU MAJ ORITY + } \\
& \beta_{4} \text { PA MAJORITY }+\beta_{5} \text { PP MINORITY }+\beta_{6} \text { PSOE MINORITY }+\beta_{7} \text { IU MINORITY + } \\
& \beta_{8} \text { PROVINC IAL G OVERNMENT }+\beta_{9} \text { GOVERNMENT SWITCH }+ \\
& \beta_{10} \text { INCOME PER CAPITA }+\beta_{11} \text { PUBUC EMPLOYMENT }+\beta_{12} \text { POLITICALCYCLE }+ \\
& \beta_{13} \text { URBAN AG G LOMERATION }+\beta_{14} \text { CONSORTUM }+\beta_{15} \text { POPULATION }+ \\
& \beta_{16} \text { SQ UARE OF POPULATIO N }+\beta_{17} \text { FINANCIAL BURDEN }+ \\
& \beta_{18} \text { CAPTATION SYSTEM }+\varepsilon_{\text {PRNATSATION }}
\end{aligned}
$$

where ( $\varepsilon_{\text {CONTRACTNG out, }} \varepsilon_{\text {PRINATSATION }}$ ) is a zero-mean unit-variance bivariate normal random variable with correlation ( $\varepsilon$ conTRACTNG OUT, $\varepsilon$ PRVATISATION $)=\rho$.

The estimation of this two-equation probit selection model yields unbiased estimates of the parameters of interest when the emor tems of expressions (3) and (4) are correlated. Nonetheless, when the errors are uncorrelated each separate equation can be consistently estimated yielding unbiased estimates of the parameters of interests (Cameron and Trivedi 2009). In this paper, we have estimated our two-equation probit selection model by maximum likelihood using Stata 10 software. However, at standard confidence levels, the estimated correlation between the emors is not significantly different from zero (the p-value for the likelihood-ratio test is 0.695 ), and the hypothesis that the two equations are independent cannot be rejected.

Then, in Table 2 we present the results from the estimation of equations (3) and (4) independently. The sign of the estimated parameters of each significant explanatory variable yields its effect, either positive or negative, on the likelihood of contracting-out and privatisation, respectively. Additionally, the magnitude of this effect is qua ntified by the marginal effect.

\subsection{Results: Deteminants of the Decision to Contract out}

The equation of the deteminants of the decision to contract out is globally significant according to the Wald test (the p-value is negligible). Similarly, with a pseudo- $R^{2}$ of 0.343 , the goodness of fit is high in comparison to similar studies. The percentage of correct answers provided by the model stands a round $80 \%$ for both results, as shown by the classific ation of observations in Table 3. 
As regards the variables representing the ideology of the local govemment, the municipalities govemed by the two parties with the most support, PSOE (centre-left) and PP (centre-right), are more likely to contract out the urban water service. This result holds regardless of both parties having a majority or minority govemment. However, the variables representing the left-wing govemment IU and the regional party PA are not significant when explaining the decision to contract out the municipal water service. It is consequently worth highlighting that the strategies of the two largest parties disputing the centre of the Spanish political spectrum do not differ as regards the decision to contract out the urban water service.

The estimated sign and statistic al signific ance of the parameter associated to the variable PROVINCIAL GOVERNMENT shows that when parties of the same ideology coincide in the municipal and provincial govemment, the probability of the service being contracted out is greater. Likewise, the negative sign and significance of the variable PUBUC EMPLOYMENT reveals that municipalities with a larger proportion of public employees are more reluctant to contract out the urban water service. In this sense, it is reasonable to believe that water service workers are the first to oppose contracting out, as this could entail signific ant changes in their working conditions. The pressure exerted by these civil servants may later receive the support of workers in other public services, who may think they will be the next to be affected by the local govemment's policy to contract out.

The results also show that administrative acknowledgement of the existence of urban agglomerations and the creation of consortiums boost the contracting out of the water service. The municipalities that are part of these associations contract out the management of the urban water service to a body that centralises the activity for the entire area. As highlighted in the literature, the strategy a ims to make the most of the significant economies of scale that exist in the water industry (González-Gómez and García-Rubio, 2008).

Finally, in reference to the rest of the variables included in the model, but not directly related to political or ideological aspects, the following results are worth highlighting. In the first place, the larger the municipality, as measured by the variable POPULATION, the greater the likelihood of the urban water service being contracted out. However, it is a decreasing effect and the probability of contracting 
out can even fall when a munic ipality surpasses a certain size. This is a common result in the literature which can be explained by the reasons given in Section 2 . These include the fact that the water supply service becomes more complex the larger the town, which can lead some councils to seek the know-how of an external manager.

In the second place, in light of the sign obtained for the variable FINANCIAL BURDEN, the local govemments with financial problems opt more for contracting out the municipal water service. Seeking out an extemal manager is one way of guaranteeing the provision of general interest services and, at the same time, to correct local govemment financial imbalances. Finally, in the municipalities where water captation requires the use of mechanical means, variable CAPTATION SYSTEM, the likelihood of contracting out the service is greater. This result is also an indication of the relationship that exists between the technical complexity of providing the water service and contracting out.

\subsection{Results: Public or Private Management?}

The model of the deteminants of the urban water service, public or private, after the decision has been made to contract out, is globally signific ant according to the Wald test (the $p$-value is 0.001 ). However, with a pseudo- $R^{2}$ of 0.137 , the goodness of fit is slightly worse than for the previous model. The model also has slightly less forecasting power, recording between $68 \%$ and $74 \%$ (Table 4 ). The variable PA MINORITY was not included in this model due to perfect multicollinearity problems. Likewise, a new variable has been introduced, PoLTCAL CYCLE, which indic ates whether the decision to privatise is taken in the first half of the legislature or the second. This variable aims to capture the possible influence of the political cycle in local govemment decision making. If it is taken into account that simply announcing the privatisation of the water service nomally sparks an adverse reaction from the general public (González-Gómez et al. 2009), it is logical to assume that this measure would be adopted early on in the legislature, in the hope that voters will have forgotten about it by the next elections. ${ }^{7}$

\footnotetext{
7 While it would have been desirable to verify whether the variable PoumCAL CYCLE also affected the decision to contract out the service, this was not possible, as including this variable in the equation of
} 
As regards the variables representing politic al ideology, only IU MAJ ORITY is significant. The negative sign of the parameter estimated suggests this left-wing party rejects delegating the management of the water service to a private fim. According to the estimated value of the marginal effect, ceteris paribus, if IU holds a majority, the probability of privatising decreases by $37.4 \%$. In other words, the city councils govemed with a majority by IU are not as in favour of contracting out the urban water service as other political parties. Furthemore, when this happens, they are more inclined to delegate management to a public company. Meanwhile, the two largest parties that occupy the centre of the politic al spectrum, PSOE and $\mathrm{PP}$, are once again seen to have the same strategy when choosing a manager, either public or private, of the urban water service. The need to occupy the centre of the political spectrum leads these two parties to converge in many of their political dec isions.

As is the case with the equation of contracting out determinants, the variable PROVINC IAL GOVERNMENT has a positive sign and is statistically signific ant. In this case, coinciding govemment signs also appear to favour the decision to privatise. The variable POLTICAL CYCLE is statistically significant and has a positive sign, hence contradicting our expectation that the most unpopular decision, that of privatising the urban water service, would be taken in the first half of the legislature. However, this result could be due to the drawn-out procedure of public calls for proposals and concession licences under Spanish law and also to bureaucracy, which substantially delay privatisation. As a result, even if the decision to privatise is taken in the first half of the legislature, it is highly possible that it will not take effect until the second half.

Munic ipalities that belong to an urban agglomeration are less likely to contract out the management of the urban water service, as indicated by the sign and significance of the variable URBAN AGGLOMERATION. Regional govemment acknowledgement of the existence of an urban agglomeration is precisely linked to the intention of promoting joint management of services in the munic ipalities that

the contracting-out determinants would have created significant multicollinearity problems. Nevertheless, the political cycle is more likely to affect the decision of privatising than contracting out, as people are less opposed to contracting out to a public company than to the privatisation of the service. 
are members of the agglomeration. In such cases, the regional govemment itself could act as a promoter of public management of the water service.

In line with the results obtained by other researchers, the estimated signs for the parameters that accompany the variables POPULATION, INCOME PER CAPITA, FINANCIAL BURDEN and CAPTATION SYSTEM suggest that private fims tend to procure the urban water service in munic ipalities where their activity is expected to yield higher profits. Private fims prefer to operate in the most populated cities where mechanical means are not required to extract the water. In these cities, the investment per inhabitant and, therefore, the average cost of the service, are lower. Furthemore, they prefer cities with a higher average level of income, where profits will foreseeably be higher and there will be fewer problems related to managing the payment of bills. Finally, private firms avoid providing the urban water service in municipalities with serious financial problems. The reason is that a concession awarded by such municipalities would probably require demanding investment plans to be undertaken, as the water supply networks can be expected to be in worse condition due to said financial problems.

\section{SUMMARY AND CONCLUSIONS}

The research on the deteminants of local political decisions regarding the management of municipal senvices generally concludes that said decisions are based on pragmatic reasons, while ideological and political motives are of little importance. While not intending to refute this assertion, in this paper we argue that in the case of certa in municipal services, such as the urban water service, a more in-depth analysis is required of how ideological and political motivations can influence local political decisions regarding their management.

The aim of this paper is to analyse the influence of ideological and political motives on the choice of management for the urban water service made by the local govemments of 734 munic ipalities located in the south of Spain, for the period 1986-2006. Unlike most previous research, we included a detailed set of variables representing ideologic al and political motivations. Furthemore, as proposed by recent studies, the values of the variables that expla in govemment decisions are observed at the time they are taken rather than at a laterdate. 
In reference to our findings, the answer to the question do ideological and political motives really matter in the public choice of urban water service management? would be that they do have a certa in influence. As regards ideology, IU -the most left-wing Spanish political party- is less in favour of contracting out the service than PP and PSOE -on the centre-right and centre-left respectively of the Spanish political spectrum. Likewise, if the service is contracted out, the likelihood of privatisation is signific antly lower when IU govems with a majority. In other words, IU prefers public management of the urban water service, either run by the town council itself or through a public company, ahead of other management options.

Similarly, the strategies of the two largest parties that dispute the centre of the Spanish political spectrum, PP and PSOE, are not signific antly different where the management of the urban water service is concemed. When both parties are in power, either with a majority or minority, the probability of the service being contracted out is greater. Moreover, once the decision to contract out has been taken, no differences are observed between the two parties in regard to their choice of either public or private management.

As far as political motivations are concemed, we find that local govemments are less likely to contract out the urban water service in munic ipa lities with a larger proportion of public employees. In such cases, city councils can give in to the pressure of public employees and not contract out the service. Likewise, the fact that there is a greater probability of the water service being privatised in areas where the service is expected to yield higher profits appears to confirm lobbies' influence over local govemment decisions. In contrast, our expectations in regard to the existence of a political cycle in decision making were not fulfilled, as the likelihood of the urban water service being privatised is greater over the last half of local govemments' terms. This could above all be due to the drawn-out administrative procedures demanded by Spanish legislation in order to privatise municipal services.

Finally, the results of this study enable us to make some recommendations for future work in this field of research. In the first place, in order to capture the influence of ideological variables on local govemment management choices, it may not be enough to distinguish between left and right-wing parties. Instead, and information permitting, it would be preferable to introduce variables that represent 
the ideology of all political parties. The largest parties, nomally those which dispute the centre of the political spectrum, tend to converge in many of their decisions. Researchers are therefore more likely to find differences in political decisions when the parties that are closer to ideological extremes are taken into account.

In addition, and in the second place, we recommend distinguishing between the different forms of management that a local govemment can opt for. The reason is that the influence of political and ideological factors on contracting out may differ, as in fact was the case in this research, to the influence they have on the choice of public or private management. Finally, insofar as it would improve the explanatory power of the models, we recommend including the value of explanatory variables at the time local govemment decisions are taken and not at a later date, as is the case in the best part of the research ca mied out in this field. This issue is particularly important when variables are subject to significant changes over time.

\section{REFrRENCES}

Bakker, K. (2002). From state to market? Water mercantilización in Spain. Environment and Planning A, 34(5), 769-790.

Bel, G., \& Fageda, X. (2007). Why do local govemments privatize public services? A survey of empiric al studies. Local G ovemment Stud ies, 33(4), 517-534.

Bel, G., \& Fageda, X. (2008). Reforming the local public sector. economics and politics in privatization of water and solid waste. Joumal of Economic Policy Reform, 11(1), 45-65.

Bel, G., \& Fageda, X. (2009a). Factors explaining local privatization: a metaregression ana lysis. Public Choice, 139(1), 105-119.

Bel, G., \& Fageda, X. (2009b). Partial privatization in local services delivery: An empirical a nalysis on the choice of mixed firms. Local Govemment Studies, Forthcoming.

Bel, G., Fageda, X., \& Mur, M. (2009). ¿Por qué se privatizan servicios en los munic ipios (pequeños)? Evidencia empíica sobre residuos sólidos y agua. Hacienda Pública Española. Revista de Economía. In Press.

Besley, T., \& Coate, S. (1997). An economic model of representative democracy. Quarterly J oumal of Ec onomics, 112(1), 85-114.

Black, D. (1958). The theory of committees and elections. Cambridge: University Press. 
Buchanan, J. M., \& Tullock, G. (1962). The Calculus of Consent. (Mi): University of Michigan Press.

Cameron, A.C., \& Trivedi, P.K. (2009). Microeconometrics: methods and a pplic ations. Cambridge University Press: New York.

Carpentier, A., Nauges, C., Reynaud, A., \& Thomas, A. (2006). Effets de la délégation sur le prix de l'eau potable en France: Une analyse à partir de la littérature sur les effets de tra itement. Ec onomie et Prévision, 174(3), 1-20.

Dixit, A., \& Londregan, J. (1998). Ideology, Tactics, and Efficiency in Redistributive Politic s. Quarterly J oumal of Ec onomic S, 113(2), 497-529.

Downs, A. (1957). An economic theory of democracy. Harperand Row.

Femis, J. (1986). The decision to contract out: an empirical a nalysis. Urban Affairs Quarterly, 22(2), 289-311.

González-Gómez, F., \& García-Rubio, M.A. (2008). Efficiency in the management of urban water services. What have we leamed after four decades of research? Hacienda Pública Española. Revista de Economía Pública, 185(2), 39-67.

González-Gómez, F., \& Guardiola, J . (2009). A duration model for the estimation of the contracting-out of urban water management in Southem Spain. Urban Affa irs Review, 44(6), 886-906.

González-Gómez, F., Guardiola, J., \& Ruiz-Villaverde, A. (2009). Reconsidering privatization in the govemance of water in Spain. Municipal Engineer, 162(3), 159-164.

González-Gómez, F., Picazo-Tadeo, A.J., \& Guardiola, J. (2010). Why do local govemments privatise the provision of water services? Empinical evidence from Spa in. Public Administration, forthcoming.

Heckman, J J . (1979). Sample selection bias as a specific ation error. Ec onometrica, 47(1), 153-161.

Lindbeck, A., \& Weibull, J.W. (1987). Balanced-budget redistribution as the outcome of politic al competition. Public Choice, 52(3), 273-297.

Martínez-Espiñeira, R., García-Valiñas, M.A., \& González-Gómez, F. (2009). Does private management of water supply services really increase prices? An empiric al a na lysis. Urban Studies, 46(4), 923-945.

Miralles, A. (2009). A duration model a nalysis of privatization of municipal of water services. Revista de Economía Aplicada, XVII(50), 47-75.

Ménard, C., \& Saussier, S. (2000). Contractual choice and performance: the case of water supply in France. Revue d'Éc onomie Industrielle, 92(2-3), 385-404.

Niskanen, W. A. (1971). Bureaucracy and representative govemment. Chicago: Ald ine Publishing.

Osbome, M.J., \& Slivinski, A. (1996). A model of political competition with citizencandidates. Quarterly J oumal of Ec onomics, 111(1), 65-96.

Stigler, G. J . (1965). The Economist and the State. The American Economic Review, $55(1 / 2), 1-18$. 
Tavares, A.F., \& Camöes, P.J. (2007) Local senvice delivery choices in Portugal: A politic al transaction costs framework. Loc al G ovemment Stud ies, 33(4), 535-553.

Van de Ven, W., \& Van Praag, B. (1981) The demand for deductibles in private health insurance. A probit model with simple selection. J oumal of Econometric s, 17(2), 229-252.

\section{TABIES AND HGURES}

Figure 1.- The management of urban water services in Andalusia, 2006

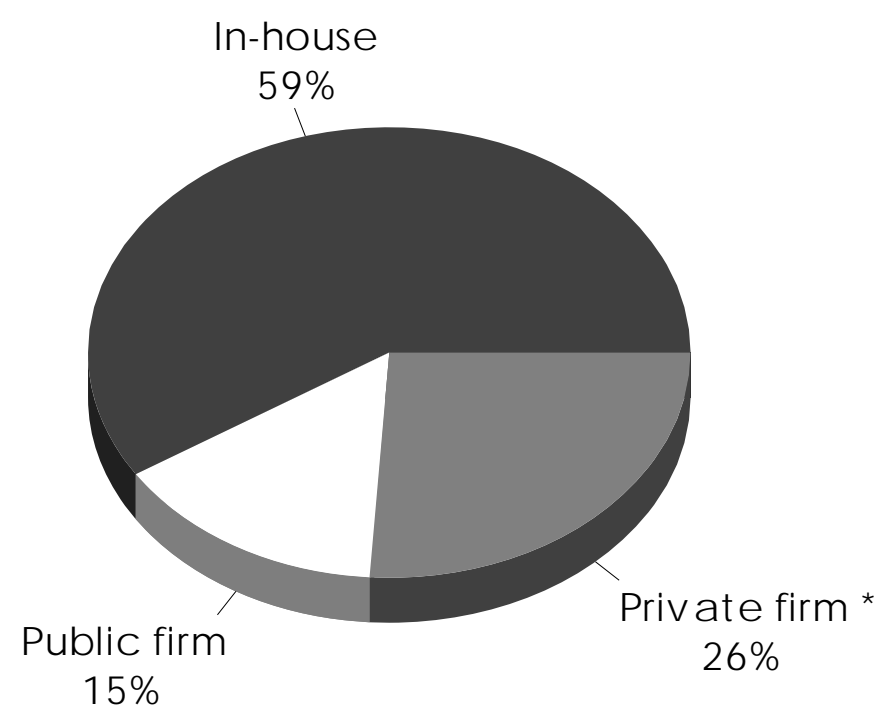

*Including public-private partnerships 
Table 1.- Sample description

\begin{tabular}{|c|c|c|c|c|c|c|c|c|}
\hline \multirow[b]{2}{*}{ Variable } & \multicolumn{4}{|c|}{ All munic ipa lities (734) } & \multicolumn{4}{|c|}{ Munic ipa lities contra c ting-out (301) } \\
\hline & Mean a & $\begin{array}{l}\text { Standard } \\
\text { deviation }\end{array}$ & Minimum & Maximum & Meana & $\begin{array}{l}\text { Standard } \\
\text { deviation }\end{array}$ & Minimum & Maximum \\
\hline CONTRACTING-OUT & 0.4108 & - & 0 & 1 & - & - & - & - \\
\hline PRIVATISATION & - & - & - & - & 0.6445 & - & 0 & 1 \\
\hline PP MAJORITY & 0.1376 & - & 0 & 1 & 0.0831 & - & 0 & 1 \\
\hline PSOEMAJORITY & 0.3488 & - & 0 & 1 & 0.5149 & - & 0 & 1 \\
\hline IU MAJ ORITY & 0.0518 & - & 0 & 1 & 0.0299 & - & 0 & 1 \\
\hline PA MAJORITY & 0.0217 & - & 0 & 1 & 0.0099 & - & 0 & 1 \\
\hline PP MINORITY & 0.0463 & - & 0 & 1 & 0.0465 & - & 0 & 1 \\
\hline PSOE MINORITY & 0.0858 & - & 0 & 1 & 0.1595 & - & 0 & 1 \\
\hline IU MINORITY & 0.0354 & - & 0 & 1 & 0.0232 & - & 0 & 1 \\
\hline PA MINORITY & 0.0191 & - & 0 & 1 & 0.0131 & - & 0 & 1 \\
\hline PROVINCIALG OVERNMENT & 0.8079 & - & 0 & 1 & 0.8870 & - & 0 & 1 \\
\hline GOVERNMENTSWITCH & 0.4578 & - & 0 & 1 & 0.9401 & - & 0 & 1 \\
\hline INCOME PER CAPITA & 2,253 & 899 & 369 & 8,100 & 2,427 & 1,056 & 386 & 8,100 \\
\hline PUBUC EMPLOYMENT & 9.14 & 5.44 & 0 & 42.62 & 8.00 & 3.53 & 0 & 23.62 \\
\hline POLTICAL CYCLE & - & - & - & - & 0.6943 & - & 0 & 1 \\
\hline URBAN AG GLO MERATION & 0.2221 & - & 0 & 1 & 0.3355 & - & 0 & 1 \\
\hline CONSORTIUM & 0.2882 & - & 0 & 1 & 0.3953 & - & 0 & 1 \\
\hline POPULATION & 7.36 & 24.75 & 0.1 & 503.25 & 13.42 & 36.69 & 0.1 & 503.25 \\
\hline FINANCIALBURDEN & 3.739 & 2.857 & 0.001 & 25.597 & 5.016 & 2.997 & 0.074 & 25.323 \\
\hline CAPTATION SYSTEM & 0.7043 & - & 0 & 1 & 0.8372 & - & 0 & 1 \\
\hline
\end{tabular}

a The mean for the qualitative variables represents the percentage of cases with value 1 . 
Table 2.- Determinants of the choice of the manager of urban water services

\begin{tabular}{|c|c|c|c|c|c|c|}
\hline \multirow[b]{2}{*}{ Variable } & \multicolumn{3}{|c|}{ In house versus contracting-out } & \multicolumn{3}{|c|}{ Public firm versus private firm } \\
\hline & $\begin{array}{r}\text { Estimated } \\
\text { parameter a }\end{array}$ & $\begin{array}{r}\text { Standard } \\
\text { error }\end{array}$ & $\begin{array}{l}\text { Marginal } \\
\text { effect } b\end{array}$ & $\begin{array}{l}\text { Estimated } \\
\text { parameter a }\end{array}$ & $\begin{array}{r}\text { Standard } \\
\text { error }\end{array}$ & $\begin{array}{r}\text { Marginal } \\
\text { effect } b\end{array}$ \\
\hline PP MAJORITY & $0.6784^{* * *}$ & 0.2237 & 0.2648 & -0.1760 & 0.3725 & - \\
\hline PSOE MAJORITY & $1.1690^{* * *}$ & 0.1552 & 0.4371 & -0.1672 & 0.2469 & - \\
\hline IU MAJORITY & -0.1636 & 0.2598 & 6. & $-0.9792^{* *}$ & 0.4826 & -0.3744 \\
\hline PA MAJORITY & -0.6072 & 0.5449 & - & -0.2057 & 0.7161 & \\
\hline PP MINORITY & $0.7737^{* * *}$ & 0.2741 & 0.3010 & -0.0242 & 0.3881 & - \\
\hline PSOE MINORITY & $1.4937^{* * *}$ & 0.2409 & 0.5249 & 0.2826 & 0.3034 & - \\
\hline IU MINORITY & 0.2279 & 0.3012 & - & 0.0986 & 0.6252 & - \\
\hline PA MINORITY & -0.4084 & 0.4897 & - & - & - & - \\
\hline PROVINCIALGOVERNMENT & $0.6210^{* * *}$ & 0.1704 & 0.2149 & $0.5433^{*}$ & 0.3031 & 0.2111 \\
\hline GOVERNMENTSWITCH & -0.1579 & 0.1474 & - & 0.1792 & 0.2181 & - \\
\hline INCOME PER CAPITA & $8.4 e-5$ & $6.7 e-5$ & - & $2.0 \mathrm{e}-4^{* * *}$ & $0.8 e-4$ & $0.7 e-4$ \\
\hline PUBபC EMPLOYMENT & $-0.0403^{* 2 k}$ & 0.0110 & -0.0152 & -0.0094 & 0.0235 & - \\
\hline POLITCAL CYCLE & - & - & - & $0.4590^{* * k}$ & 0.1735 & 0.1741 \\
\hline URBAN AG GLOMERATION & $0.5128^{* * *}$ & 0.1476 & 0.1993 & $-0.4176^{* *}$ & 0.1797 & -0.1577 \\
\hline CONSORTUM & $0.7018^{* * *}$ & 0.1340 & 0.2705 & -0.0880 & 0.1693 & - \\
\hline POPULATION & $0.0232^{* *}$ & 0.0090 & 0.0087 & $0.0342^{* * k}$ & 0.0108 & 0.0127 \\
\hline SQUARE OF POPULATION & $-4.7 e-8^{* * k}$ & $1.7 e-8$ & $-1.8 e-8$ & $-1.4 e-8^{* 2 k}$ & $4.8 e-8$ & $-5.1 e-8$ \\
\hline FINANCIALBURDEN & $0.1143^{\text {**** }}$ & 0.0273 & 0.0433 & $-0.1123^{\text {*ak }}$ & 0.0392 & -0.0417 \\
\hline CAPTATIO N SYSTEM & $0.5578^{* * *}$ & 0.1305 & 0.2005 & $-0.5489^{* *}$ & 0.2394 & -0.1852 \\
\hline CONSTANT & $-2.5070^{* * k}$ & 0.3165 & - & 0.1291 & 0.5491 & - \\
\hline Log pseudo-likelihood & \multicolumn{3}{|c|}{-326.12} & \\
\hline Wald test $\left(\chi^{2}\right)^{c}$ & \multicolumn{3}{|c|}{$201.05(0.0000)$} & \multicolumn{3}{|c|}{$41.90(0.0011)$} \\
\hline Pseudo $\mathrm{R}^{2}$ & \multicolumn{3}{|c|}{0.343} & \multicolumn{3}{|c|}{0.1377} \\
\hline Observations & \multicolumn{3}{|c|}{734} & \multicolumn{3}{|c|}{301} \\
\hline
\end{tabular}

a * Signific a nt at $10 \%$, * signific a nt at $5 \%$ and ${ }^{* * *}$ signific a nt at $1 \%$.

b The marginal effects a re only presented for statistic ally signific a nt variables.

c Probability of no signific ance of the model between brackets. 
Table 3.- Prediction power of equation (3): determinants of c ontracting-out

\begin{tabular}{|c|cc|c|}
\cline { 2 - 4 } \multicolumn{1}{c|}{} & \multicolumn{2}{c|}{ Classified } & \multicolumn{1}{c}{} \\
\hline Observed & In house (0) & Contracting-out (1) & Total \\
\hline In house (0) & 374 & 59 & 433 \\
Contracting-out (1) & 86 & 215 & 301 \\
\hline Total & 460 & 274 & 734 \\
\hline Hits & $81,3 \%$ & $78,4 \%$ & \multicolumn{1}{|c}{} \\
\hline
\end{tabular}

Table 4.- Prediction power of equation (4): determinants of privatisation

\begin{tabular}{|c|cc|c|}
\cline { 2 - 3 } \multicolumn{1}{c|}{} & \multicolumn{2}{c|}{ Classified } & \multirow{2}{*}{ Total } \\
\hline Observed & Public fim (0) & Private fim (1) & 107 \\
\hline Public firm (0) & 47 & 60 & 194 \\
\hline Private fim (1) & 22 & 172 & 301 \\
\hline Total & 69 & 232 & \multicolumn{1}{c}{} \\
\hline Hits & $68,1 \%$ & $74,1 \%$ & \\
\end{tabular}




\section{Appendix 1. Variables: Description and sources}

\begin{tabular}{|c|c|c|}
\hline Variable & Description & Source \\
\hline $\begin{array}{l}\text { CONTRACTING- } \\
\text { OUT }\end{array}$ & $\begin{array}{l}\text { Dummy variable that takes a value of } 1 \text { if the council has contracted out urban water } \\
\text { services at the end of the period } 1986-2006 \text { and } 0 \text { otherwise }\end{array}$ & $\begin{array}{l}\text { Town councils and public and } \\
\text { private fims }\end{array}$ \\
\hline PRIVATISATION & $\begin{array}{l}\text { Dummy variable that takes a value of } 1 \text { if the council has privatised the management } \\
\text { of urban water servic es at the end of the period } 1986-2006 \text { and } 0 \text { if the service has } \\
\text { been contracted out to a public firm }\end{array}$ & $\begin{array}{l}\text { Town councils and public and } \\
\text { private fims }\end{array}$ \\
\hline PP MAYORITY & $\begin{array}{l}\text { Dummy variable that equals } 1 \text { if PP was in power in the local govemment with the } \\
\text { majority of votes when the decision of contracting out was taken. If the municipa lity } \\
\text { did not contract out, it equals } 1 \text { if this party was in power with a majority of votes at } \\
\text { the end of the period. Otherwise, this variable takes a value of } 0\end{array}$ & $\begin{array}{l}\text { Home Office (Local Elections } \\
\text { Results) a nd Ministry of Regional } \\
\text { Policy (Register of Mayors) }\end{array}$ \\
\hline PSOE MAYORITY & $\begin{array}{l}\text { Dummy variable that equals } 1 \text { if PSOE was in power in the local govemment with the } \\
\text { majority of votes when the decision of contracting out wastaken. If the munic ipa lity } \\
\text { did not contract out, it equals } 1 \text { if this party was in power with a majority of votes at } \\
\text { the end of the period. Otherwise, this variable takes a value of } 0\end{array}$ & $\begin{array}{l}\text { Home Office (Local Elections } \\
\text { Results) a nd Ministry of Regional } \\
\text { Polic y (Register of Mayors) }\end{array}$ \\
\hline IU MAYORITY & $\begin{array}{l}\text { Dummy va riable that equals } 1 \text { if IU was in power in the local govemment with the } \\
\text { majority of votes when the decision of contracting out was taken. If the munic ipa lity } \\
\text { did not contract out, it equals } 1 \text { if this party was in power with a majority of votes at } \\
\text { the end of the period. Otherwise, this variable takes a value of } 0\end{array}$ & $\begin{array}{l}\text { Home Office (Local Elections } \\
\text { Results) a nd Ministry of Regional } \\
\text { Policy (Register of Mayors) }\end{array}$ \\
\hline PA MAYORITY & $\begin{array}{l}\text { Dummy variable that equals } 1 \text { if PA was in power in the local govemment with the } \\
\text { majority of votes when the decision of contracting out was taken. If the municipa lity } \\
\text { did not contract out, it equals } 1 \text { if this party was in power with a majority of votes at } \\
\text { the end of the period. Otherwise, this variable takes a value of } 0\end{array}$ & $\begin{array}{l}\text { Home Office (Local Elections } \\
\text { Results) a nd Ministry of Regional } \\
\text { Policy (Register of Mayors) }\end{array}$ \\
\hline PP MINO RITY & $\begin{array}{l}\text { Dummy va riable that equals } 1 \text { if PP had a minority of votes and was in power in the } \\
\text { local govemment when the decision of contracting out was taken. If the munic ipality } \\
\text { did not contract out, it equals } 1 \text { if this party was in power with a minority of votes at the } \\
\text { end of the period. Otherwise, this variable takes a value of } 0\end{array}$ & $\begin{array}{l}\text { Home Office (Local Elec tions } \\
\text { Results) a nd Ministry of Regional } \\
\text { Polic y (Register of Mayors) }\end{array}$ \\
\hline PSOE MINORITY & $\begin{array}{l}\text { Dummy va riable that equals } 1 \text { if PSO E had a minority of votes and was in power in the } \\
\text { local govemment when the decision of contracting was taken out. If the munic ipality } \\
\text { did not contract out, it equals } 1 \text { if this party was in power with a minority of votes at the } \\
\text { end of the period. Otherwise, this variable takes a value of } 0\end{array}$ & $\begin{array}{l}\text { Home Office (Local Elec tions } \\
\text { Results) a nd Ministry of Regional } \\
\text { Polic y (Register of Mayors) }\end{array}$ \\
\hline
\end{tabular}




\section{Appendix 1. Variables: Description and sources (Continuation)}

\begin{tabular}{|c|c|c|}
\hline Variable & Description & Source \\
\hline IU MINORITY & $\begin{array}{l}\text { Dummy variable that equals } 1 \text { if IU had a minority of votes and was in power in the } \\
\text { local govemment when the decision of contracting out was taken. If the munic ipality } \\
\text { did not contract out, it equals } 1 \text { if this party was in power with a minority of votes at the } \\
\text { end of the period. Otherwise, this variable takes a value of } 0\end{array}$ & $\begin{array}{l}\text { Home Office (Local Elections } \\
\text { Results) and Ministry of Regional } \\
\text { Policy (Register of Mayors) }\end{array}$ \\
\hline PA MINORITY & $\begin{array}{l}\text { Dummy va riable that equals } 1 \text { if PA had a minority of votes and was in power in the } \\
\text { local govemment when the decision of contracting was taken out. If the munic ipality } \\
\text { did not contract out, it equals } 1 \text { if this party was in power with a minority of votes at the } \\
\text { end of the period. Otherwise, this variable takes a value of } 0\end{array}$ & $\begin{array}{l}\text { Home Office (Local Elections } \\
\text { Results) and Ministry of Regional } \\
\text { Policy (Register of Mayors) }\end{array}$ \\
\hline $\begin{array}{l}\text { PROVINCIAL } \\
\text { GOVERNMENT }\end{array}$ & $\begin{array}{l}\text { Dummy va riable that equals } 1 \text { if the ideology of the provincial and municipal } \\
\text { govemments coincides when the dec ision of contracting out wastaken, and } 0 \text { if it } \\
\text { does not coincide. If the munic ipality did not contract out, it takes the comesponding } \\
\text { value at the end of the period }\end{array}$ & Home Office (Elections Results) \\
\hline $\begin{array}{l}\text { GOVERNMENT } \\
\text { SWITCH }\end{array}$ & $\begin{array}{l}\text { This dummy variable equals } 1 \text { if the munic ipality contracts out and the decision is } \\
\text { taken by a recently elected govemment, if the munic ipality did not contract out and } \\
\text { if there has been a change of govemment during the period considered. } \\
\text { Conversely, it takes a value of } 0 \text { if the munic ipa lity contracts out and the decision is } \\
\text { taken by a govemment already established in power, if the munic ipality did not con- } \\
\text { tract out and if there has been no change of govemment during the period }\end{array}$ & $\begin{array}{l}\text { Ministry of Regional Policy } \\
\text { (Register of Mayors) }\end{array}$ \\
\hline $\begin{array}{l}\text { INCOME PER } \\
\text { CAPITA }\end{array}$ & $\begin{array}{l}\text { Euros per inhabitant. If the munic ipa lity contracts out, it takes the value from the year } \\
\text { before contracting out. In the case of not contracting out, it takes the average value } \\
\text { over the period }\end{array}$ & $\begin{array}{l}\text { Andalusia Regional } \\
\text { Govemment (Department of } \\
\text { Economic Affairs and Public } \\
\text { Finances) }\end{array}$ \\
\hline $\begin{array}{l}\text { PUBUC } \\
\text { EMPLOYMENT }\end{array}$ & $\begin{array}{l}\text { Percentage of public employment. If the munic ipality contracts out, it takes the value } \\
\text { from the year before the decision. If not, it takes the average value over the period. }\end{array}$ & $\begin{array}{l}\text { Andalusia Regional } \\
\text { Govemment (Department of } \\
\text { Economic Affa irs and Public } \\
\text { Finances) }\end{array}$ \\
\hline POUTICALCYCLE & $\begin{array}{l}\text { Dummy variable that takes a value of } 1 \text { if the municipa lity contracts out within the two } \\
\text { first years of govemment and } 0 \text { if it contracts out in the third or fourth years of } \\
\text { govemment }\end{array}$ & $\begin{array}{l}\text { Town councils and public and } \\
\text { private fims }\end{array}$ \\
\hline $\begin{array}{l}\text { URBAN } \\
\text { AGGLOMERATTON }\end{array}$ & $\begin{array}{l}\text { Dummy va riable that takes a value of } 1 \text { if the munic ipality belongs to an urban ag- } \\
\text { glomeration and } 0 \text { otherwise }\end{array}$ & $\begin{array}{l}\text { Andalusia Regional } \\
\text { Govemment }\end{array}$ \\
\hline
\end{tabular}




\section{Appendix 1. Variables: Description and sources (Continuation)}

\begin{tabular}{|c|c|c|}
\hline Variable & Description & Source \\
\hline CONSORTIUM & $\begin{array}{l}\text { In the case of contracting out, this dummy variable takes a value of } 1 \text { if the council } \\
\text { was integrated in a consortium the previous yearand } 0 \text { otherwise. In the case of not } \\
\text { contracting out, it takesa value of } 1 \text { if the munic ipality belongs to a consortium in the } \\
\text { middle of the period and } 0 \text { if not }\end{array}$ & $\begin{array}{l}\text { Ministry of Regional Policy } \\
\text { (Register of Consortiums) }\end{array}$ \\
\hline POPULATION & $\begin{array}{l}\text { Population in } 1,000 \text { s of inhabitants. If the munic ipality contracts out, it takes the value } \\
\text { from the year prior to contracting out. In the case of not contracting out, it takes the } \\
\text { average value over the period }\end{array}$ & $\begin{array}{l}\text { National Institute of Sta tistics } \\
\text { (Munic ipal Census) }\end{array}$ \\
\hline $\begin{array}{l}\text { FINANCIAL } \\
\text { BURDEN }\end{array}$ & $\begin{array}{l}\text { Sum of fina ncial expenditures over sum of ordinary revenues of the local govemment. } \\
\text { In the case of contracting out, this variable takes the value at the year before the } \\
\text { decision wastaken. In the case of not contracting out, it takes the mean over the } \\
\text { period }\end{array}$ & $\begin{array}{l}\text { Ministry of Economic Affa irs } \\
\text { (Local C orporations Budget) }\end{array}$ \\
\hline $\begin{array}{l}\text { CAPTATION } \\
\text { SYSTEM }\end{array}$ & $\begin{array}{l}\text { Dummy variable taking a value of } 1 \text { if water is captured using mechanical means and } \\
0 \text { if it is captured using the force of gravity }\end{array}$ & $\begin{array}{l}\text { Ministry of Regional Policy (Local } \\
\text { Infrastruc tures and Equipment } \\
\text { Survey) and Ministry of Health } \\
\text { and Consumption (C onsumption } \\
\text { Water National Information } \\
\text { System) }\end{array}$ \\
\hline
\end{tabular}

